\title{
Competition Indicator in Alfalfa Populations Following Recurrent Selection to Glyphosate Tolerance
}

\author{
M. Abd El-Sattar Ahmed ${ }^{1 *}$, Ahlam, H. Mostafa ${ }^{2}$, Thanaa. I. Milad ${ }^{3}$, and T.A. Mahmoud ${ }^{4}$ \\ 1 Professor, Crop Science Dept., Fac.Agric. (El-Shatby), Alexandria university (Mohamed.A@alexu.edu.eg) \\ 2 Researcher, forage crops section, ARC, Nubaria, Egypt. \\ 3 Professor, Crop Science Dept., Fac.Agric. (El-Shatby), Alexandria university. (s.i.milad@alexu.edu.eg) \\ 4 Head Research,forage crops section, ARC, Nubaria, Egypt. \\ *; corresponding author.
}

\begin{abstract}
The bad cide in adopting cide-tolerant alfalfa cultivar is the shift in weed communities with rise proportion of tolerant species. The main objective of the recent study was to trace competition indicator of alfalfa populations as affected by recurrent selection to glyphosate tolerance. Two cycles of recurrent selection for Glyphosate tolerance were imposed on each base population. Competition indicators following selection included plant characters and weed bioassay. In most studied populations, plant height decreased with the first cycle of selection to glyphosate tolerance by $-8.991,-3.225,-1.240$ and $-0.426 \%$ in Siwa, Hasawi, C.U.F101 and Baladi1 populations, respectively. Except for, Sirivar population an increase by $+6.740 \%$ was accompanied with selection to glyphosate tolerance. On the other hand, by cycle two of selection, populations had different response relative to C1, where Baladi1, C.U.F101 and Sirivar populations had a decrease in plant height with values reached $-1.761,-0.720$ and $0.617 \mathrm{~cm}$, respectively. While, Hasawi and Siwa populations showed an increased plant height by +3.816 and $+3.197 \mathrm{~cm}$, respectively. Glyphosate treated plots (+ and -) were evaluated by weed bioassay in terms of green and dry weight during a course of three successive cuttings. Exposed genetic materials to glyphosate treatments were selection cycles $\left(\mathrm{C}_{0}, \mathrm{C}_{1}\right.$ and $\left.\mathrm{C}_{2}\right)$ of the five studied populations. The first cycle of selection to glyphosate tolerance expressed a significant increase of 9.59 and $10.93 \%$ relative to the base population as green and dry weed weights, when evaluated under glyphosate treating condition. The second cycle of selection was associated with a reduction of 29.63 and $28.88 \%$ in green and dry weight of weed. This might indicate a proliferation of alfalfa plants that were selected for glyphosate tolerance, the matter that reduced the mass of weeds, whether, as green or dry weight.
\end{abstract}

Keywords: Competition, Alfalfa,Populations, Recurrent Selection, Glyphosate tolerance, Tillering, Plant height, Weed bioassay.

\section{INTRODUCTION}

Alfalfa "Medicago sativa, L." that has large genetic diversity, is among the most important forage crops "king of forages". That provided alfalfa genotypes to occupy different environments. The importance of alfalfa forage goes to its high content of protein and minerals, besides, high degree of palatability. Volunteer weeds in alfalfa fields are mostly of lower quality and palatability, especially "Urospermum picriods" and "Xanthium spinosus". That affect the value and persistence of alfalfa fields.

The early seedling stage of alfalfa is the most vulnerable to weed competition. Weed hazards extend up to the third cutting of the establishment year. Selective herbicides as a control measure in alfalfa fields were used very little. That goes to its high price, limited effectiveness and herbicidal injury. Glyphosate is a systemic non-selective foliar applied herbicide. Irrespective of glyphosate non- selectivity, several plant species exhibit levels of tolerance to its effect (Gottrup, et al.,1976), reductions to sorption and limited translocation from vegetative to reproductive organs (Neal et al.,1985). Several trials have been made to select a glyphosate tolerance genotypes in vitro. In each of them tolerance was due to an increase in 5enolpyruvy shikimate 3-phosphate synthase (EPSPS) activity (Shah et al. 1986).

The registration of the new alfalfa variety Roundup Ready ® started by mid-2005. The new variety came-up after the translocation of resistance- give to alfalfa germplasm. That enable the new plant to resist the effects of general eradication herbicide "glyphosate". The good consequences of adopting such new type of cultivars includes an improvement in yield, quality and turn- over. Also, glyphosate is a short- durated herbicide in soil, with very limited influences on soil Flora and Fauna, besides, salt- effect on mammals. The bad cide in adopting cide-tolerant alfalfa cultivar is the shift in weed communities with rise proportion of tolerant species. Miller et al. (2006), summarized the benefits of using Rundup Ready ( alfalfa in North states as ; 1) 
better control of noxious- weed species, 2) insure less botanical injury- indicators, 3) Provide flexible management practice regarding the time of application, prevailing weather, 4) reduce weed competition allowing for better establishment and good forage quality, 5) ensure the use of pretested safe- herbicide, and 6) secure high quality hay free- from noxious weeds. The expected increase in yield with this new technology reached about 1.4 to 3.3 ton. acre $^{-1}$ Late application of glyphosate to alfalfa Fields caused a reduction in yield reached 0.3 to 0.8 ton. ha ${ }^{1}$. Orloff and Putnam (2011). Discussed the good and bad consequences of used roundup ready alfalfa cultivar. Growers of alfalfa at majority were satisfied with good consequences of new cultivar. They related their acceptance to this new cultivar to good limitation of weed competition, flexible application, and potentiality of eliminating bad weeds. They also reported a higher forage yield and better-quality forage. Green, (2012), explained the merits of relaying on glyphosate resistant crops rather than changing the used herbicide seeking for more efficient weed control system. The merits of the first strategy depend on using single herbicide (glyphosate), which is common to farmers with easy, effective, economic and environmentally friendly sides. He added that, the efficiency of glyphosate in eradicating weeds is not equal to all species, consequently some species acquire resistance, driving the control system relaying on glyphosate resistance to be unsustainable. He advised using integrated weed management systems to conserve sustainability.

Karim and Bradshaw, 1968, recommended the selection for herbicide- resistance in crop plants. There must be no consideration to loss of fitness with progress of selection for herbicideresistance, since, crop plants undergone generations of selection.

Research results regarding improvement of alfalfa tolerance to glyphosate in Egypt is relatively scare. The main objective of the recent study was to trace competition indicator of alfalfa populations as affected by recurrent selection to glyphosate tolerance.

\section{MATERIALS AND METHODS}

Alfalfa plant materials (Medicago sativa, L.) used in that recent study will be referred to five base populations. Two cycles of recurrent selection for Glyphosate tolerance were imposed on each of five base populations. (C.U.F 101 population Pedigree was (University of California Davis, UC 76, 1972, released by C.U.F seed company). Siriver population (Hunter river x C.U.F 101 and UC 110 and UC 112),.Hasawi population is a land race naturally originated on Saudi Arabia. Baldi1 population Selected from EL-Wadi EL-Gedid landrace by Forage Research Department of ARC, Egypt. Siwa population is a land race naturally originated on Siwa Oasis of western-desert, Egypt.

Cycle one was practiced on 2800 plants per each base population $\left(\mathrm{C}_{0}\right)$. Base populations were seeded at density of 100 plant. $\mathrm{m}^{-2}$ (considering seed index and germination percentages). Each germplasm seeded in $28 \mathrm{~m}^{2}$ (20 rows of $1.75 \mathrm{~m}$ long and $0.80 \mathrm{~m}$ apart) on Nubaria Agricultural Research Station, North of Egypt. Seeding date was, May $27^{\text {th }}, 2015$. Four weeks after seeding, plants $(8-15 \mathrm{~cm}$ tall) were treated with $0.56 \mathrm{~kg}$ acid equivalent per hectare $\left(\mathrm{ae}^{-\mathrm{ha}^{-1}}\right.$ ) of Glyphosate (Round up®) diluted in 480 liter of water (L). Survived plants were left to complete the first cutting growth (two months). Regrowth of the second cutting at $20-25 \mathrm{~cm}$ height was sprayed by $0.84 \mathrm{~kg}$ ae. $\mathrm{ha}^{-1}$ glyphosate in $480 \mathrm{~L}$ water. ha ${ }^{1} .14$ day after treatment, plants was rated for injury on a 1 to 4 scale (where 1= uninjured, 2=injured shoot, $3=$ dead shoot with live auxiliary shoots and $4=$ dead seeding) (Boerboom et al.,1991). The uninjured plants were selected uprooted and transplanted to an isolated plots surrounded and covered by insect proof cloth for flowering and seed setting .Plants selected for Glyphosate tolerance from each germplasm were 100 plant .Each germplasm was caged separately in cloth house and a portable honey bees heave (Apis mellifera, L.) was used as pollinators (for random matting among plants). Seeds were harvested for each separate plant as a half-sib family on June, 15 th 2016 .Equale seed weight from each selected half-sib family seeds were bulked to from first improved cycle $\left(\mathrm{C}_{1}\right)$. The second cycle of selection was practiced for each separate improved population. Each population was seeded in 20 rows of $1.25 \mathrm{~m}$. long and $0.80 \mathrm{~m}$ apart (2000 plant). Four-week-old seedlings were treated with Glyphosate at $0.56 \mathrm{~kg}$ ae. $\mathrm{ha}^{-1}$ in 480 liters of water. Fourteen days after treatment, injury levels were rated as 1= uninjured, 2=injured shoot, $3=$ dead shoot with live auxiliary shoots and $4=$ dead seeding. The uninjured plants were selected uprooted and transplanted to an isolated plot surrounded and covered by insect proof cloth for flowering and seed setting. Plants selected for Glyphosate tolerance from each germplasm were 100 plant. Each germplasm was caged separately in cloth house and a portable honeybees heave (Apis mellifera L.) was used as pollinators (for random matting among plants). Seeds were harvested for each separate plant as a half-sib family on June, $15^{\text {th }}$, 2017.Equale seed weight from each selected half-sib family seeds were bulked to from second improved cycle $\left(\mathrm{C}_{2}\right)$. 
Evaluation of selected cycles $\left(\mathrm{C}_{1}\right.$ and $\left.\mathrm{C}_{2}\right)$ along with base populations $\left(\mathrm{C}_{0}\right)$ was carried out for each population as a split plot design with Glyphosate treatment (+ and -) as main plots and populations $\left(\mathrm{C}_{0}, \mathrm{C}_{1}\right.$ and $\left.\mathrm{C}_{2}\right)$ as a sub -plot. Four replicates were used. Plot size was three rows of $1.80 \mathrm{~m}$ long and $0.15 \mathrm{~m}$ apart. Planting of seeds took place at November $1^{\text {st }}$, 2017. Glyphosate treatment was applied 30 days after planting at $0.84 \mathrm{~kg}$ ae. ha ${ }^{-1}$ in 480 liters of water.

Glyphosate treated and untreated plots were evaluated for the following characters:

i- Plant characters: including the following measurements:

1-plant height $(\mathrm{cm})$ :as an average of five readings per plot.

2-Number of stems (tilleringpotentiality): counted per a rectangle of $25 \times 25 \mathrm{~cm}$ during the successive nine cuttings of evaluation.

ii- Weeds bioassay.

During a three successive cutting of evaluation, weeds were traced in each plot by placing a quadrate of $0.25 \times 0.25 \mathrm{~m}$. Fresh and dry weights of weeds were considered.

Data of all experiments were subjected to analysis of variance according to Cochran and Cox, 1957. Means were separated by a protected L.S.D. test (Fisher, 1960). M stat-c package was used in all analysis.

\section{RESULTS AND DISCUSSION}

\section{Plant characters:}

Plant characters i.e., plant height $(\mathrm{cm})$ and number of stems $10.0625 \mathrm{~m}^{2}$ in all treated and untreated plots by glyphosate, were detected. Table (1) illustrated the mean squares of plant characters (plant height and number of stems) for alfalfa base populations and selection cycles as effected by glyphosate treatment. Significant $(p \geq 0.01)$ variations were detected among the glyphosate treatment, alfalfa populations and the interaction between population and selection cycles for plant height and number of stems. While, number of stems had significant variation $(\mathrm{p} \geq 0.01)$ due to glyphosate $\mathrm{x}$ population $\mathrm{x}$ selection cycles interaction.

Table (1): Mean squares of plant characters for alfalfa base population and selection cycles affected by glyphosate.

\begin{tabular}{|l|c|c|c|}
\hline \multirow{2}{*}{ S.O.V } & \multirow{2}{*}{ d.f. } & Mean of Plant height & Mean of Number of stems \\
\cline { 3 - 4 } & 1 & $2127^{* *}$ & $2547^{* *}$ \\
\hline Glyphosate treatment (G) & 3 & 35.90 & 26.39 \\
Rep /Glyphosate & & & \\
Population (P) & 4 & $38.76^{* *}$ & $23.08^{* *}$ \\
GXP & 4 & $9.268^{*}$ & $78.40^{* *}$ \\
Selection cycles (S) & 2 & $9.836^{*}$ & $27.78^{* *}$ \\
GXS & 2 & $3.395^{\text {n.s }}$ & $1.249^{\text {n. s }}$ \\
PXS & 8 & $33.29^{* *}$ & $19.26^{* *}$ \\
GXPXS & 8 & $5.002^{\text {n.s }}$ & $15.33^{* *}$ \\
Error & 84 & 2.927 & 2.515 \\
\hline
\end{tabular}

*, **; significant at 0.05 and 0.01 levels, respectively.

n.s: not significantly different at 0.05 level of probability.

Table (2), presented mean values of plant characters (plant height $(\mathrm{cm})$ and number of stems) as affected by main effect of the studied factors (glyphosate, alfalfa populations and selection cycles). As for, plant height $(\mathrm{cm})$, untreated alfalfa had taller plants than untreated plants (69.48 and $61.06 \mathrm{~cm}$, respectively). Also, population showed variable plant height over glyphosate treatment and selection cycles. Three of the five studied populations expressed similar plant heights $(66.29$, 66.69 and $65.17 \mathrm{~cm}$ for Hasawi, Siriver and Baladi1 populations respectively). While, both of C.U.F 101 and Siwa populations, enjoyed similarly shorter stems $(64.69$ and $63.52 \mathrm{~cm}$ for C.U.F 101 and Siwa populations respectively). The first cycle of selection for glyphosate tolerance was accompanied with significant reduction in plant height $(65.77$ and $64.78 \mathrm{~cm}$ for base population and cycle one of selection, respectively). Meanwhile, further selection cycle $\left(\mathrm{C}_{2}\right)$ was associated with a stem length regain to reach that of the base population $(65.26 \mathrm{~cm}$ for cycle two).

Regarding mean number of stems for glyphosate treatments, alfalfa populations and selection cycles (Table 2), glyphosate treated plots had a smaller number of stems than treated plots (31.28 vs. 40.50 stems for treated and untreated plots, respectively). Also, the studied alfalfa populations 
expressed different number of stems over glyphosate treatments and selection cycles, where, C.U.F101 and Siwa enjoyed the highest significant number of stems (36.89 cmstemfollowed by Siriver populations. with number of stems (35.96 and 36.78 stem, respectively). Also, both of Siriverand Hasawi populations were similar in tillering (35.96 and 35.14 stems, respectively). In the meantime, Hasawi and Baladi 1 produced significantly similar number of stems per unit area (35.14 and 34.67 plants, respectively). Meanwhile, the first cycle of selection for glyphosate tolerance, although was accompanied with lower number of stems per unit area, that reduction had not reached the level of significance (35.61 and 35.23 stems for $\mathrm{C}_{0}$ and $\mathrm{C}_{1}$ respectively). The second cycle of selection for glyphosate tolerance was associated with better tillering that significantly expressed higher number of stems per unit area (36.83 plants).

Table (2): Mean of plant characters for Glyphosate treatments, alfalfa populations and selection cycles.

\begin{tabular}{|l|l|c|c|}
\hline \multicolumn{1}{|c}{ Factors } & \multicolumn{1}{|c|}{ Levels of factor } & $\begin{array}{c}\text { Mean of plant height } \\
\text { (cm) }\end{array}$ & $\begin{array}{c}\text { Mean of number of } \\
\text { stems }\end{array}$ \\
\hline \multirow{3}{*}{ Glyphosate } & Treated & 61.06 & 31.28 \\
\cline { 2 - 4 } & Untreated & 69.48 & 40.50 \\
\hline \multirow{2}{*}{ L.S.D 0.05} & & 2.676 & 2.295 \\
\hline \multirow{3}{*}{ Population } & C.U.F 101 & 64.69 & 36.89 \\
\cline { 2 - 4 } & Hasawi & 66.29 & 35.14 \\
\cline { 2 - 4 } & Sirivar & 66.69 & 35.96 \\
\cline { 2 - 4 } & Baladi 1 & 65.17 & 34.67 \\
\cline { 2 - 4 } & Siwa & 63.52 & 36.78 \\
\hline L.S.D 0.05 & & 0.977 & 0.906 \\
\hline \multirow{2}{*}{ Selection cycles } & $\mathrm{C}_{0}$ & 65.77 & 35.61 \\
\cline { 2 - 4 } & $\mathrm{C}_{1}$ & 64.78 & 35.23 \\
\cline { 2 - 4 } & $\mathrm{C}_{2}$ & 65.26 & 36.83 \\
\hline \multirow{2}{*}{ L.S.D 0.05} & & 0.757 & 0.702 \\
\hline
\end{tabular}

Table (3), presented the effect of the interaction between alfalfa populations and glyphosate treatments. In general, the untreated plants in all studied base populations were of taller plants relative to glyphosate treated populations. Untreated populations of Hasawi and Siriver enjoyed significantly similar taller plants (71.01 and $70.78 \mathrm{~cm}$, respectively). While, Siwa population, significantly showed the shortest stems when treated with glyphosate $(58.54 \mathrm{~cm})$. It was valuable to notice that population response to glyphosate treatment in term of reduction in plant height was descending from Siwa to Hasawi to Siriver to C.U.F 101 to Baladil as 14.6, 13.3, 11.5, 10.8 and $10.4 \%$ reduction, respectively.

Concerning the effect of glyphosate treatment $x$ population interaction on alfalfa plant tillering expressed as number of stems per unit area (Table`3), untreated plots gave significantly higher number of stems in all studied populations. The least significant tillering was that of Baladi 1 population under glyphosate treatment (27.57 stems), while, the highest tillering was expressed by any of CUF 101, Baladi 1 and Siwa populations with no glyphosate treatment $(41.62,41.79$ and 41.05 for the three populations, respectively). The vulnerability of the studied alfalfa populations to glyphosate treatment in term of reduction in tillering was highest in Baladi 1 population that showed $34.03 \%$ reduction in tillering ability. While, both of C.U.F101 and Hasawiwere of similar vulnerability with reduction in tillering reached 22.71 and $24.54 \%$, respectively. In the meantime, both of Siriver and Siwa population were the least vulnerable with tillering reduction of 10.73 and $13.45 \%$, respectively.

Table (4) represented the effect of the interaction between alfalfa populations and selection cycle on plant height $(\mathrm{cm})$. In most studied populations, plant height decreased with the first cycle of selection to glyphosate tolerance by $-8.991,-3.225,-1.240$ and $-0.426 \%$ in Siwa, Hasawi, C.U.F101 and Baladi1 populations, respectively. Except for, Sirivar population an increase by $+6.740 \%$ was accompanied with selection to glyphosate tolerance. On the other hand, by cycle two of selection populations had different response relative to $\mathrm{C} 1$, where Baladi1, C.U.F101 and Sirivar populations had a decrease in plant height with values reached $-1.761,-0.720$ and $0.617 \mathrm{~cm}$, respectively. While,Hasawiand Siwa populations showed an increased plant height by +3.816 and $+3.197 \mathrm{~cm}$, respectively. 
Table (3): Mean of plant characters for the interaction between alfalfa populations and glyphosate treatment

\begin{tabular}{|l|c|c|c|c|}
\hline \multirow{2}{*}{ Population } & \multicolumn{2}{|c|}{ Mean of Plant height(cm) } & \multicolumn{2}{c|}{ Mean of Number of stems } \\
\cline { 2 - 5 } & Treated & Untreated & Treated & Untreated \\
\hline C.U.F 101 & 60.99 & 68.39 & 32.17 & 41.62 \\
\hline Hasawi & 61.57 & 71.01 & 30.25 & 40.04 \\
\hline Sirivar & 62.61 & 70.78 & 33.93 & 38.01 \\
\hline Baladi 1 & 61.60 & 68.74 & 27.57 & 41.79 \\
\hline Siwa & 58.54 & 68.51 & 32.53 & 41.05 \\
\hline L.S.D 0.05 & \multicolumn{3}{|c|}{1.382} & \\
\hline
\end{tabular}

Table (4): Mean of plant characters for alfalfa base population and selection cycles affected by Glyphosate

\begin{tabular}{|c|c|c|c|c|c|c|c|}
\hline \multirow[b]{2}{*}{ Population } & \multirow{2}{*}{$\begin{array}{c}\text { Selection } \\
\text { cycle }\end{array}$} & \multirow{2}{*}{$\begin{array}{c}\text { Mean } \\
\text { of Plant } \\
\text { height }(\mathbf{c m})\end{array}$} & \multicolumn{2}{|c|}{ Relative to } & \multirow{2}{*}{$\begin{array}{c}\text { Mean of } \\
\text { Number of } \\
\text { stems } \\
\end{array}$} & \multicolumn{2}{|c|}{ Relative to } \\
\hline & & & $\mathbf{C}_{0}$ & $\mathbf{C}_{1}$ & & $\mathbf{C}_{0}$ & $\mathbf{C}_{1}$ \\
\hline \multirow{3}{*}{ C.U.F 101} & $\mathrm{C}_{0}$ & 65.39 & & & 37.09 & & \\
\hline & $\mathrm{C}_{1}$ & 64.58 & $-1.249^{\mathrm{n} . \mathrm{s}}$ & & 36.87 & $-0.598^{\mathrm{n} . \mathrm{s}}$ & \\
\hline & $\mathrm{C}_{2}$ & 64.11 & & $-0.720^{\mathrm{n} . \mathrm{s}}$ & 36.71 & & -0.447 \\
\hline \multirow{3}{*}{ Hasawi } & $\mathrm{C}_{0}$ & 66.91 & & & 33.00 & & \\
\hline & $\mathrm{C}_{1}$ & 64.75 & $-3.225^{*}$ & & 35.76 & $8.345^{*}$ & \\
\hline & $\mathrm{C}_{2}$ & 67.22 & & $3.816^{*}$ & 36.68 & & 2.587 \\
\hline \multirow{3}{*}{ Sirivar } & $\mathrm{C}_{0}$ & 63.96 & & & 37.81 & & \\
\hline & $\mathrm{C}_{1}$ & 68.27 & $6.740^{*}$ & & 33.79 & $-10.612^{*}$ & \\
\hline & $\mathrm{C}_{2}$ & 67.85 & & $-0.617^{\mathrm{n} . \mathrm{s}}$ & 36.31 & & 7.433 \\
\hline \multirow{3}{*}{ Baladi 1} & $\mathrm{C}_{0}$ & 65.74 & & & 34.39 & & \\
\hline & $\mathrm{C}_{1}$ & 65.46 & $-0.426^{\mathrm{n} . \mathrm{s}}$ & & 34.59 & $0.521^{\mathrm{n} . \mathrm{s}}$ & \\
\hline & $\mathrm{C}_{2}$ & 64.31 & & $-1.761^{\mathrm{n} . \mathrm{s}}$ & 35.07 & & $1.452^{\mathrm{n} . \mathrm{s}}$ \\
\hline \multirow{3}{*}{ Siwa } & $\mathrm{C}_{0}$ & 66.89 & & & 35.79 & & \\
\hline & $\mathrm{C}_{1}$ & 60.87 & $-8.991^{*}$ & & 35.18 & $-1.715^{\mathrm{n} . \mathrm{s}}$ & \\
\hline & $\mathrm{C}_{2}$ & 62.82 & & $3.197^{*}$ & 39.39 & & $11.96^{*}$ \\
\hline L.S.D 0.05 & & \multicolumn{3}{|c|}{1.693} & \multicolumn{3}{|c|}{1.570} \\
\hline
\end{tabular}

These results match true with the findings recorded by Dekker and Duke 1995. They Said that, the production of glyphosate-resistant crops has been the focus of much research for over a decade. A major problem in the production of glyphosate resistant plants is that its glyphosate is readily translocated to meristems and other metabolic sinks, where, it is concentrated to levels many times that found in leaves. Furthermore, it is not metabolically degraded to a significant extent. So, although the plant may be resistant at the foliar level, the concentrations that accumulate in meristems, flower buds, and other metabolic sinks may overwhelm the resistance mechanism. Johal and Huber (2009), said that, indirect effects of glyphosate on disease predisposition result from immobilization of specific micronutrients involved in disease resistance, reduced growth and vigor of the plant from accumulation of glyphosate in meristematic root, shoot, and reproductive tissues, altered physiological efficiency, or modification of the soil microflora affecting the availability of nutrients involved in physiological disease resistance. Vereecken, (2005) said that, glyphosate can form chelates or complexes with micronutrient metal ions in solution. At physiologically relevant $\mathrm{pH}$ levels, and $\mathrm{pH}$ levels of most soils, $\mathrm{Cu}$ and $\mathrm{Zn}$ ions in solution can be relatively strongly complexed with glyphosate, whereas $\mathrm{Fe}, \mathrm{Ca}, \mathrm{Mg}$, and $\mathrm{Mn}$ are complexed to lesser degrees. The ability of glyphosate to complex metal ions, glyphosate has been postulated to affect plant uptake of trace nutrients such as $\mathrm{Mn} 2+$ or $\mathrm{Zn} 2+$. For plants grown in hydroponic solutions, mixed results for glyphosate effects on plants have been shown. 
Tillering capacity of alfalfa plants represented by number of stems per unit area as affected by the interaction between population and selection cycle (Table 4) showed that alfalfa population significantly varied in response to selection for glyphosate tolerance, since, the first cycle of selection to tolerance gave reduction in tillering capacity of C.U.F101, Siriver and Siwa populations (-0.598, 10.612 and $-1.715 \%$, respectively). That reduction was only significant for the first two populations. The progress of selection for glyphosate tolerance $\left(\mathrm{C}_{2}\right)$ gave insignificant negative (C.U.F101) or positive (Hasawi and Baladi 1) response. While, expressed significant positive response reached 7.433 and $11.96 \%$ relative to tillering potentiality in cycle one of Siriver and Siwa populations, respectively.

The second order interaction among alfalfa population $\times$ selection cycle $\times$ glyphosate treatment reflected on tillering capacity as number of stems per unit area was presented in Table 5. Evaluation of selection cycles of all populations under glyphosate treatments, showed significantly lower number of stems relative to the corresponding values under no glyphosate treatment. The magnitude of tillering response to glyphosate treatment varied among populations and selection cycles. In C.U.F 101 population, a reduction in tillering was associated with each of first and second cycle of selection, although, had not reached the level of selection $(-1.397$ and $-1.363 \%$ relative to each of cycle one and cycle two, respectively). In Hassawi population under glyphosate treatment, selection for tolerance was associated with an increase in tillering reached 6.948 and $12.08 \%$ relative to $\mathrm{C}_{1}$ and $\mathrm{C}_{2}$, respectively. The effect of the second cycle of selection had reached the level of significance. In both of Siriver and Baladi populations, although tillering under glyphosate treatment was noticed, that change had not reached the level of significance. The soundest change in tillering potentiality was recorded with Siwapopulation, since, a significant reduction of $-13.75 \%$ relative to $\left(\mathrm{C}_{0}\right)$ was associated with the first cycle of selection to glyphosate tolerance. One the other hand, a significant increase of $23.18 \%$ relative to cycle two of selection was achieved in plant tillering. It was valuable to notice that the base populations of Hassawi, Baladi lcycles and cycle one of Siwa presented the least tillering potentiality.

Evaluation of population's cycles under no glyphosate treatment showed that, only Siriver and Siwa population's cycles had showed significant response to selection for glyphosate tolerance. In Siriver population, the first cycle of selection expressed a significant reduction of $-16.55 \%$ tillering relative to base population. While,the second cycle gave appositive significantresponse of $+12.77 \%$ relative to first cycle. But in common, selected cycles expressed significantly lower tillering that the base population. In Siwa population, the two successive cycles of selection gained higher tillering reached 8.791 and $4.208 \%$ relative to each of the preceding cycles, respectively. The tillering of selected cycles was superior to base population.

Commonly, selection for glyphosate tolerance affected the tillering capacity of alfalfa populations with variable magnitudes only in Siwa population, the second cycle of selection improved tillering capacity over the first cycle or the base population when evaluated under no glyphosate treatment.

These results match true with the findings recorded by Zobiole et al.2011, they suggest that applying glyphosate at early growth stages using the lowest glyphosate rate might have less damage on growth and productivity of RR soybeans.

\section{Weed bioassay:}

Glyphosate treated plots (+ and -) were evaluated by weed bioassay in terms of green and dry weight during a course of three successive cuttings. Exposed genetic materials to glyphosate treatments were selection cycles $(\mathrm{C} 0, \mathrm{C} 1$ and $\mathrm{C} 2)$ of the five studied populations. Mean squares of weeds and dry bioassay for alfalfa populations and selection cycles as affected by glyphosate treatments were presented in Table 6. Glyphosate treatments significantly $(\mathrm{P} \geq 0.01)$ influenced green bioassay of weeds. Also, the studied populations significantly $(P \geq 0.01)$ varied in response to weed invasion and growth determined as green or dry biomass (significant glyphosate $\times$ population interaction), along with significant variations among populations to weed invasion and development (green and dry bioassay). The tendency of the studied selection cycles to influence to weed development as a green weight was significantly $(\mathrm{P} \geq 0.01)$ different. Also, the competition of selected cycles to weeds was significantly influenced by glyphosate treatments (significant glyphosate treatments $\times$ selection cycles interaction). Meanwhile, the behavior of selected cycle as a suppressor or simulator to weed development was different $(\mathrm{P} \geq 0.01)$ in direction or magnitude by the nature of the base population from which it was originated (significant population $\times$ selection cycles interaction). Finally, for each glyphosate treatment applied to each of the studied base populations, weed development as a measure of tolerance or intolerance was significantly varied with variable selection cycles. (significant glyphosate treatments $\times$ population $\times$ selection cycles interaction). 


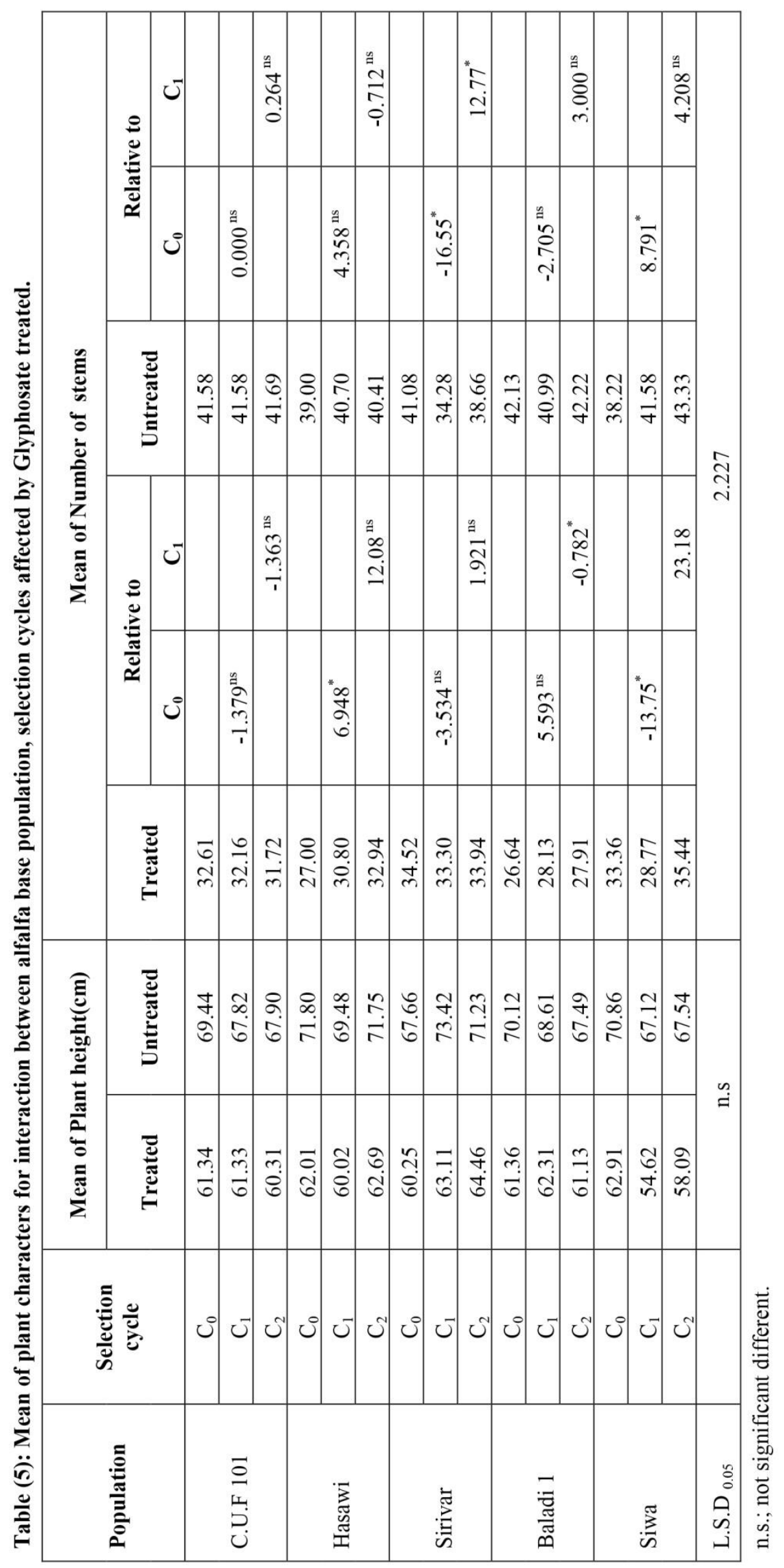


Table (6): Mean squares of weed green bioassay and weed dry bioassay for alfalfa population and selection cycles as affected by glyphosate treatments.

\begin{tabular}{|l|l|c|c|}
\hline \multirow{2}{*}{ S.O.V } & \multirow{2}{*}{ d.f. } & \multicolumn{2}{|c|}{ M.S } \\
\cline { 3 - 4 } & 1 & Green bioassy & Dry bioassy \\
\hline Glyphosate treatment (G) & 3 & $3165^{* *}$ & $978.9^{\text {n.s. }}$ \\
Rep /Glyphosate & 4 & $1496^{* *}$ & 218.6 \\
\hline Population (P) & 4 & $2737^{* *}$ & $692.2^{* *}$ \\
GXP & 2 & $2037^{* *}$ & $1298^{* *}$ \\
Selection cycles (S) & 2 & $1872^{* *}$ & $387.9^{\text {n.s }}$ \\
GXS & 8 & $2564^{* *}$ & $920.9^{* *}$ \\
PXS & 8 & $2017^{* *}$ & $753.7^{* *}$ \\
GXPXS & 84 & 174.2 & $441.4^{* * *}$ \\
error & & 147.8 \\
\hline
\end{tabular}

*,** significance at 0.05 and 0.01 levels of probability, respectively.

n.s.; not significantly different at 0.05 level of probability.

Means of weeds green and dry bioassay $\left(\mathrm{kg} . \mathrm{ha}^{-1}\right)$ as affected by glyphosate treatments and selection cycles were presented in Table (7). Over populations, glyphosate treatment significantly suppressed weed green weight by $13.21 \%$, while, dry weight of weeds was suppressed by $5.275 \%$. The first cycle of selection to glyphosate tolerance expressed a significant increase of 9.59 and $10.93 \%$ relative to the base population as green and dry weed weights, when evaluated under glyphosate treating condition. While, the second cycle of selection was associated with a reduction of 29.63 and $28.88 \%$ in green and dry weight of weed. This might indicate a proliferation of alfalfa plants that were selected for glyphosate tolerance, the matter the reduced the mass of weeds, whether,as green or dry weight. Evaluation of selected cycles under the absence of glyphosate application significantly expressed variable values of weed bioassay. The first selected cycles of alfalfa showed a reduction of $-3.329 \%$ in green weight of weeds. Meanwhile, the change in weed biomass as dry weight had not reached the level of significance. The second cycle of selection for glyphosate tolerance was associated with insignificant reduction in weed green weight $(-2.64 \%)$ and insignificant increase $(5.73 \%)$ in weeds dry weight. Commonly, the second cycle of selection for glyphosate tolerance significantly showed an obvious suppression to weeds green and dry weights (bioassay) when evaluated under glyphosate treatment.

The relation between selection cycles and alfalfa populations was illustrated in Table 8. C.U.F 101 base population $\left(\mathrm{C}_{0}\right)$ was subject to weed invasion. The first cycle of selection $\left(\mathrm{C}_{1}\right)$ for glyphosate tolerance significantly reduced the incidence of weeds represented by green biomass by $24.22 \%$ relative to what recorded at the base population. Additional selection $\left(\mathrm{C}_{2}\right)$ was associated with further reduction in the level of green weed biomass invasion, but, that reduction had not reached the level of significance. Hasawi base population $\left(\mathrm{C}_{0}\right)$, exhibited the heaviest green weed invasion among all studied base populations. Selection for glyphosate tolerance in Hasawi gave substantial reduction in weeds green biomass as 17.04 and $42.55 \%$ for cycle one and two, respectively. In Siriver population, the first cycle of selection for glyphosate tolerance gave significantly lower alfalfa competition, i.e; higher weed green mass invasion at a level reached $22.48 \%$ relative to weed green mass at base population. Whereas, the second cycle of selection for glyphosate tolerance suppressed weed green biomass by $13.8 \%$ relative to value of cycle one. Similar trend was expressed by Baladilpopulation in response to selection cycles with values amounted to $19.44 \%$ increase in weeds green mass after the first cycle of selection to glyphosate tolerance and $21.22 \%$ decrease after the second cycle of selection. Paradoxically, selection for glyphosate tolerance is Siwa population was associated with significant dimension in alfalfa competition, i.e; as increase in weeds green biomass reached 18.05 and $12.14 \%$ after cycle one and two relative to each preceding cycle, respectively. Commonly, weeds green biomass response to selection cycles was recorded variably among the studied base populations. A significant reduction in weed green mass was associated with one cycle of selection for glyphosate tolerance in C.U.F 101 and Hasawi populations. An opposite responsewere noticed in Siriver, Baladi and Siwapopulations. Meanwhile, the second cycle of selection for glyphosate tolerance was associated with a reduction in weeds green biomass in all studied populations, but, Siwa. Reduction or increase in weeds green mass is mostly compensated by alfalfa growth and tillering. 
Alex. J. Agric. Sci.

Vol. 65, No. 2, pp. 55-68, 2020

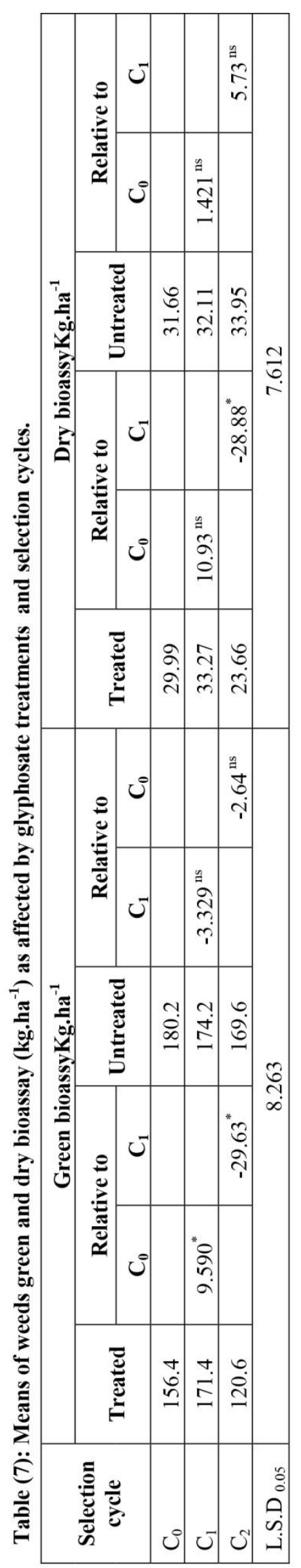


Dry mass of weeds as an indicator for alfalfa vigor and niche occupation showed that selection for glyphosate tolerance in C.U.F 101 population reduced weeds dry mass with progress of selection. That reduction had not reached the level of significance. As for Hasawi population, the only significant reduction in dry weeds mass was reached after two cycles of selection $(39.71 \%$ reduction in weeds dry mass relative to cycle one). Dry mass of weeds failed to indicate the effect of selection for glyphosate tolerance in Siriver population. In Baladi1, by the second cycle of selection, alfalfa significantly suppressed weeds dry mass by $23.46 \%$ relative to cycle one. While dry mass of weeds failed to indicate the influence of selection cycles to vigor and competition of Siwa alfalfa.

Table (8): Means of weeds green and dry bioassay ( $\mathrm{kg}^{.} \mathrm{ha}^{-1}$ ) as affected by the interaction between alfalfa populations and selection cycle

\begin{tabular}{|c|c|c|c|c|c|c|c|}
\hline \multirow{3}{*}{ Population } & \multirow{3}{*}{$\begin{array}{l}\text { Selection } \\
\text { cycle }\end{array}$} & \multicolumn{3}{|c|}{ Green Bioassay kg.ha ${ }^{-1}$} & \multicolumn{3}{|c|}{ Dry Bioassay kg.ha-1 } \\
\hline & & \multirow{2}{*}{ Means } & \multicolumn{2}{|c|}{ Relative to } & \multirow{2}{*}{ Means } & \multicolumn{2}{|c|}{ Relative to } \\
\hline & & & $\mathrm{C}_{0}$ & $\mathrm{C}_{1}$ & & $\mathrm{C}_{0}$ & $\mathrm{C}_{1}$ \\
\hline \multirow{3}{*}{ C.U.F 101} & $\mathrm{C}_{0}$ & 92.79 & & & 47.44 & & \\
\hline & $\mathrm{C}_{1}$ & 70.31 & $-24.22^{*}$ & & 37.42 & $-21.72^{\mathrm{ns}}$ & \\
\hline & $\mathrm{C}_{2}$ & 66.80 & & $-4.992^{\mathrm{ns}}$ & 40.84 & & $9.139^{\mathrm{ns}}$ \\
\hline \multirow{3}{*}{ Hasawi } & $\mathrm{C}_{0}$ & 112.8 & & & 62.33 & & \\
\hline & $\mathrm{C}_{1}$ & 93.57 & $-17.04^{*}$ & & 54.44 & $-12.65^{\mathrm{ns}}$ & \\
\hline & $\mathrm{C}_{2}$ & 53.75 & & $-42.55^{*}$ & 32.82 & & $-39.71^{*}$ \\
\hline \multirow{3}{*}{ Siriver } & $\mathrm{C}_{0}$ & 71.83 & & & 42.14 & & \\
\hline & $\mathrm{C}_{1}$ & 93.01 & $22.48^{*}$ & & 51.52 & $22.25^{\mathrm{ns}}$ & \\
\hline & $\mathrm{C}_{2}$ & 80.84 & & $-13.08^{\mathrm{ns}}$ & 45.33 & & $-12.01^{\mathrm{ns}}$ \\
\hline \multirow{3}{*}{ Baladi 1} & $\mathrm{C}_{0}$ & 90.45 & & & 48.02 & & \\
\hline & $\mathrm{C}_{1}$ & 108.04 & $19.44^{*}$ & & 61.79 & $28.67^{*}$ & \\
\hline & $\mathrm{C}_{2}$ & 85.11 & & $-21.22^{*}$ & 47.29 & & $-23.46^{*}$ \\
\hline \multirow{3}{*}{ Siwa } & $\mathrm{C}_{0}$ & 81.05 & & & 46.73 & & \\
\hline & $\mathrm{C}_{1}$ & 95.68 & $18.05^{*}$ & & 56.44 & $20.77^{\mathrm{ns}}$ & \\
\hline & $\mathrm{C}_{2}$ & 107.3 & & $12.14^{\mathrm{ns}}$ & 64.19 & & $13.73^{\mathrm{ns}}$ \\
\hline L.S.D 0.05 & & 13.06 & & & 12.03 & & \\
\hline
\end{tabular}

Evaluation of weed biomass influence to selected cycles of the studied alfalfa populations evaluated under glyphosate treatments $(+$ and - were expressed in Table 9. Green mass of weeds in base populations of C.U.F 101, Siriver and Baladi1were not affected by glyphosate treatments. While, green weed mass was suppressed by glyphosate treatment in Hasawi and Siwa populations. The first cycle of selection for glyphosate tolerance in C.U.F 101 population, resulted in a competitive alfalfa plants (reduced green mass of weeds), whether, evaluated as glyphosate positive or negative treated that effect was only noticed in Hasawipopulation under glyphosate untreated plots. Oppositely, less competitive alfalfa plants to weeds green mass were recorded in Baladiland Siwa populations under glyphosate treatment. Also, similar response was noted in Siriverpopulation when evaluated in absence of glyphosate treatment. Meanwhile, insignificant influences of cycle one selection to alfalfa competition were expressed in Hasawi and Siriver population under glyphosate treatment and Baladiland Siwa populations under no glyphosate treatment.

While, green bioassay of weeds partially explained the influence of selection to glyphosate tolerance to competitiveness and vigor of produced selection cycles, dry bioassay of weeds failed to indicate any significant influence of selection cycles and glyphosate treatments to competitiveness of alfalfa populations. 


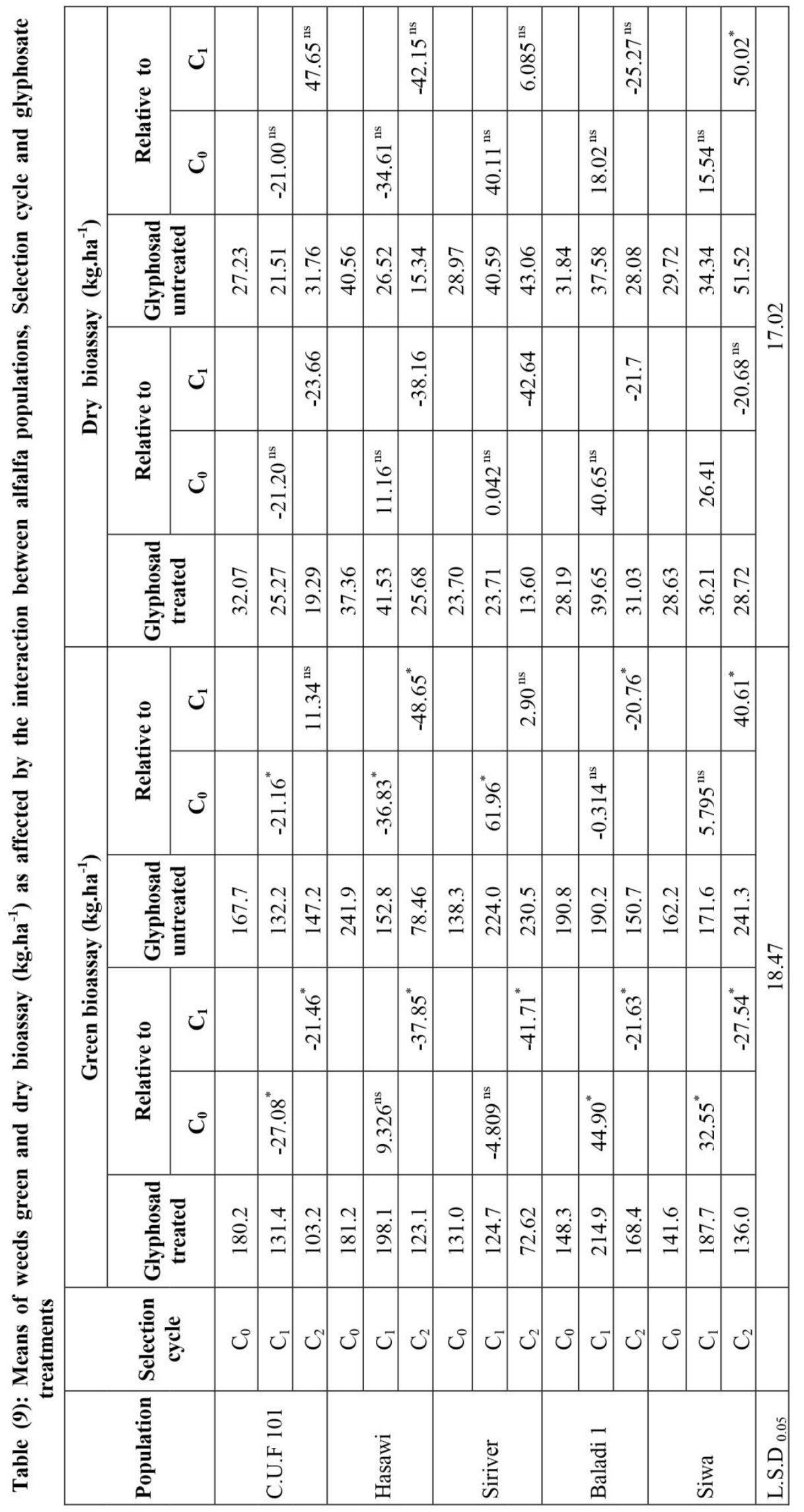


The recent results might be explained depending on the competitive relations among alfalfa plants and invading weeds. Also, reduction in plant density following glyphosate application encourage the proliferation of weeds in the niche of field. Shaner (2000), recommended the use of glyphosate as a selective, post-emergence weed control measure in glyphosate- tolerant soybean, cotton, canola and maize. Reddy (2001) stated that evaluation of entries under glyphosate treatment, determine early season weed interference to crop development. Dill et al (2008) supported last finding through recommending glyphosate- ready crops as a measure to eliminate and minimize weed invasion. Green (2012) reported that, although, glyphosate had used extremely well in controlling weeds in glyphosate- resistant crops for long times, some key weeds had evolved resistance and dominated in fields. Miller et al (2006) stated that glyphosate tolerant crops, requires application of specific herbicides to control tolerant weeds. An explanation to dispersion of weeds in a glyphosate resistant or tolerant crop field Busi and Powles (2009) stated that, selection of glyphosate tolerant crop by plants exposure to sub- lethal dose of glyphosate, includes the contribution of minor genes endowing substantial plant survival at sub lethal herbicide dose might be potential complementary path to herbicide resistance evolution in weed populations. Also, Zenk (1974) reached that, selection pressure that might be imposed in the field can rarely be made to exceed 9095\% kill, while, majority of remaining plants are "escapees" Also, high dose rate in field application, hardly increases kill of susceptible plants, but, may be lethal to the few truly resistant plants among the escapees.

\section{CONCLUSION}

The major obtained results might be summarized in the following:

\section{Plant height (cm):}

- In most studied populations, plant height decreased with the first cycle of selection to glyphosate tolerance by $-8.991,-3.225,-1.240$ and $-0.426 \%$ in Siwa, Hasawi, C.U.F101 and Baladi1 populations, respectively. Except for, Sirivar population an increase by $+6.740 \%$ was accompanied with selection to glyphosate tolerance.

- On the other hand, by cycle two of selection, populations had different response relative to $\mathrm{C} 1$, where Baladi1, C.U.F101 and Sirivar populations had a decrease in plant height with values reached $-1.761,-0.720$ and $0.617 \mathrm{~cm}$, respectively. While, Hasawiand Siwa populations showed an increased plant height by +3.816 and $+3.197 \mathrm{~cm}$, respectively.

\section{Number of stems:}

- The first cycle of selection for glyphosate tolerance, although was accompanied with lower number of stems per unit area, that reduction had not reached the level of significance (35.61 and 35.23 stems for $\mathrm{C}_{0}$ and $\mathrm{C}_{1}$ respectively).

- The second cycle of selection for glyphosate tolerance was associated with better tillering that significantly expressed higher number of stems per unit area (36.83 plants).

- Alfalfa population significantly varied in response to selection for glyphosate tolerance, since, the first cycle of selection to tolerance gave reduction in tillering capacity of C.U.F101, Siriver and Siwapopulations $(-0.598,-10.612$ and $-1.715 \%$, respectively). That reduction was only significant for the first two populations.

- The progress of selection for glyphosate tolerance $\left(\mathrm{C}_{2}\right)$ gave insignificant negative (C.U.F101) or positive (Hasawi and Baladi 1) response. While, expressed significant positive response reached 7.433 and $11.96 \%$ relative to tillering potentiality in cycle one of Siriver and Siwa populations, respectively.

\section{Weed Bioassay:}

- Glyphosate treated plots (+ and -) were evaluated by weed bioassay in terms of green and dry weight during a course of three successive cuttings. Exposed genetic materials to glyphosate treatments were selection cycles $\left(\mathrm{C}_{0}, \mathrm{C}_{1}\right.$ and $\left.\mathrm{C}_{2}\right)$ of the five studied populations.

- The first cycle of selection to glyphosate tolerance expressed a significant increase of 9.59 and $10.93 \%$ relative to the base population as green and dry weed weights, when evaluated under glyphosate treating condition.

- The second cycle of selection was associated with a reduction of 29.63 and $28.88 \%$ in green and dry weight of weed. This might indicate a proliferation of alfalfa plants that were selected for glyphosate tolerance, the matter the reduced the mass of weeds, whether,as green or dry weight

- Commonly, the second cycle of selection for glyphosate tolerance significantly showed an obvious suppression to weeds green and dry weights (bioassay) when evaluated under glyphosate treatment.

- The relation between selection cycles and alfalfa populations might be discussed as follows.

- C.U.F 101 base populations $\left(\mathrm{C}_{0}\right)$ was subject to weed invasion. The first cycle of selection $\left(C_{1}\right)$ for glyphosat tolerance significantly reduced the incidence of weeds represented by green biomass by $24.22 \%$ relative to what recorded at the base population. 
- Additional selection $\left(\mathrm{C}_{2}\right)$ was associated with further reduction in the level of green weed biomass invasion, but, that reduction had not reached the level of significance.

- Hasawi base population $\left(\mathrm{C}_{0}\right)$, exhibited the heaviest green weed invasion among all studied base populations. Selection for glyphosate tolerance in Hasawi gave substantial reduction in weeds green biomass as 17.04 and $42.55 \%$ for cycle one and two, respectively.

- In Siriverpopulation, the first cycle of selection for glyphosate tolerance gave significantly lower alfalfa competition, i.e; higher weed green mass invasion at a level reached $22.48 \%$ relative to weed green mass at base population. Whereas, the second cycle of selection for glyphosate tolerance suppressed weed green biomass by $13.8 \%$ relative to value of cycle one.

- Similar trend was expressed by Baladilpopulation in response to selection cycles with values amounted to $19.44 \%$ increase in weeds green mass after the first cycle of selection to glyphosate tolerance and $21.22 \%$ decrease after the second cycle of selection.

- Paradoxically, selection for glyphosate tolerance is Siwa population was associated with significant dimension in alfalfa competition, i.e., as increase in weeds green biomass reached 18.05 and $12.14 \%$ after cycle one and two relative to each preceding cycle, respectively.

- While, green bioassay of weeds partially explained the influence of selection to glyphosate tolerance to competitiveness and vigor of produced selection cycles, dry bioassay of weeds failed to indicate any significant influence of selection cycles and glyphosate treatments to competetiveness of alfalfa populations.

\section{LITERATURE CITED}

Boerboom C.M, N.J, Ehlke D.L Wyse and D.A Somers. 1991. Recurrent selection for glyphosate tolerance in Birdsfoot Trefoil. Crop sci. 31;1124-1129.

Busi, R. and S.B. Powles. 2009.Evalution of glyphosate resistance in a Loliumrigidum population by glyphosate selection at sublethal doses. Heredity 103; 318-325.

Cochran , W.G. and Cox,G.M.1957. Experimental Design. $2^{\text {nd }}$.John Wiley, N.Y, U.S.A.

Dekker.J. and S. O. Duke 1995. Herbicide-Resistant Field Crops. Iowa State University. http://lib.dr.iastate.edu/agron_pubs .
Dill G.M,C.A. CaJacob and S.R. Padgette 2008. Glyphosate-resistant crops: adoption, use and future considerations. Pest Manag Sci 64: 326-331.

Fisher ,R.A. 1960. The Designs of Experiments. 7 th. Ed. Oliver\&Boyd, Edinburgh.

Gottrup,O., P.AO, Sullivan, R.J.Schraa and W.H. Vanden Born. 1976. Uptake, translocation, metabolism and selectivity of glyphosate in Canada thistle and leafy spurge. Weed Res. 16-197:201.

Green.J.M.2012.The benefits of herbicide-resistant crops. Pest Manag. Sci. 68; 1323-1331.

Johal G.S.and D.M. Huber 2009. Glyphosate effects on diseases of plants. Europ. J. Agronomy 31; 144-152.

Karim, A., and A. D. Bradshaw. 1968. Genetic variation in simazine resistance in wheat, rape and mustard. Weed Res., 8; 283-29.

Miller S.D, R.G, Wilson A.R Kniss and C.M.Alford 2006.Roundup Ready® Alfalfa A new technology for high plains hay producers. Jenna Norfolk, College of Agriculture intern.

MSTAT-C.(1996). Russel, D.Freed, MSTAT Director, Crop and soil Sciences Department, Michigan State University, U.S.A.

Neal, J. C, W. A. Skrock and T.J.Monaco.1985. Effect of plant growth stage on glyphosate. Plant phsiol.,76:551-574.

Orloff. S. and Putnam .D.2011.Roundup ready ${ }^{\circledR}$ alfalfa- what have we learned to date.Western Alfalfa \& Forage Conference, http://alfalfa.ucdavis.edu.

Reddy K. N, 2001. Glyphosate-resistant soybean as a weed management tool: Opportunities and challenges. Weed Biology and Management 1;193:202.

Shah, D.M., R.B Horsch, H .J. Klee, G.M, Kishore J .A. Winter, N. E. Turner, C.M. Hironaka, P .R. Sanders, C.S .Gasser, S .Aykent, N .Siegel, S .G Rogers and R .T. Fraley,1986 . Engineering herbicide tolerance in transgenic plants .Science $233: 478-481$

Shaner, D.L.2000.The impact of glyphosate-tolerant crops on the use of other herbicides and on resistance management. Pest Manage Sci. 56,320-326.

Zenk, M. H. 1974. Haploids in physiological and biochemical research, in: "Haploids in Higher Plants: Advances and Potentials," K. J. Kasha, ed., Univ. of Guelph, Guelph, Canada.

Zobiole L. H. S, R.J Kremer, R. S. Oliveira and .J Constantin. 2011. Glyphosate affects chlorophyll, nodulation and nutrient accumulation of "second generation" glyphosate-resistant soybean (Glycine max, L.) a Pesticide Biochemistry and Physiology 99; 53-60. 


\section{دلائل القدره على المنافسه فى عثائر البرسيم الحجازى بعد الانتخاب الدورى لتحمل الجليفوسات}

محمد عبد الستار احمد و احلام حسنى مصطفى و سناء ابراهيم ميلاد و طه احمد محمود

الجانب السئ في تبني صنف البرسيم الحجازي المتحمل لمبيد الحثائش هو التغير الحادث في عثائر الحشائش مع تغلب نسبي للأنواع المتحملة. الهدف الرئيسي للدراسة الحالية هو تتبع دلائل القدرة علي المنافسة في هوي عشائر البرسيم الحجازي بعد تأثرها بالانتخاب الدوري لتحمل الجليفوسات. تم إجراء دورتان من الانتخاب الدوري لتحمل الجليفوسات لكل عشيرة من عشائر البرسيم الحجازي. وقد اعتمد علي صفات النبات والتقييم الحيوي للحشائش كدلائل للقدرة التتافسية للبرسيم الحجازي. في معظم العشائر المدروسة تتاقص إرتفاع النبات بعد الدورة

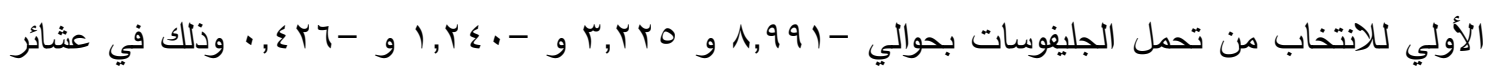
سيوة وحساوي و C.U.F. وبلدي العل علي الترتيب. وفيما عدا العثيرة ساي ريفر التي أظهرت زيادة في إرتفاع

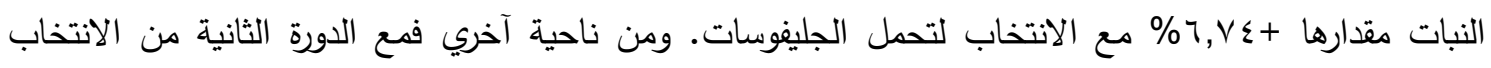
سجلت العشائر استجابة مختلفة منسوبة إلي الدورة الأولي حيث سجلت العشائر بلدي ا و C.U.F. 101 وساي ريغر

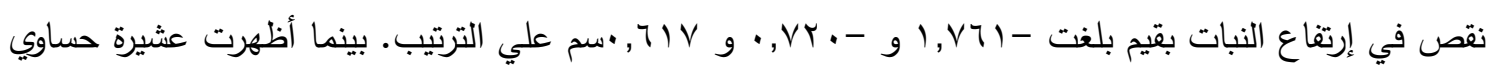

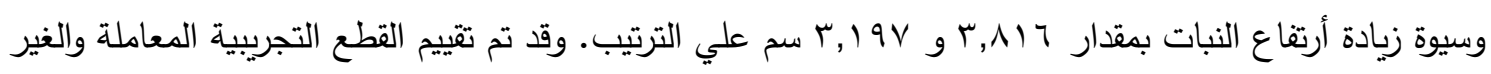
المعاملة بالجليفوسات من حيث التقييم الحيوي للحشائش معبراً عنه بالوزن الأخضر والجاف خلال ثلاث حشات متتالية , حيث تم معاملة ناتج دورات الانتخاب الأولي والثانية وعثيرة الاساس للعثائر المدروسة الخمسة بمبيد

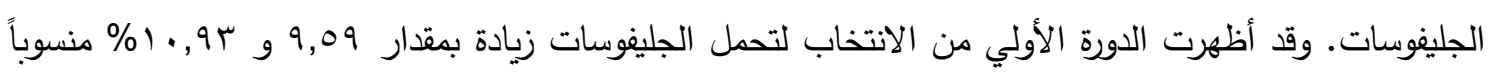
إلي عشيرة الاساس في كلً من الوزن الأخضر والوزن الجاف عند تقيمها تحت ظروف الرش بالجليفوسات أما

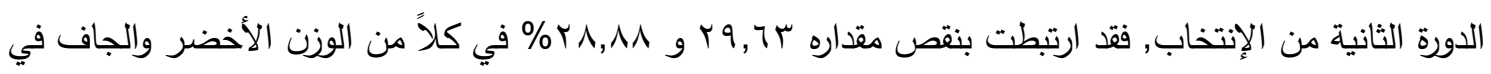
الحشائش وقد يعبر هذا عن زيادة في القدرة التتافسية لنباتات البرسيم الحجازي التي تم إنتخابها لتحمل مبيد الجليفوسات. 